\title{
Hypnoteaching to Improve Motoric Skills in Physical Education
}

\author{
Samsul Azhar ${ }^{*}$, Dewi Shinta Nor Aini ${ }^{2}$, Silvi Aryanti ${ }^{2}$ \\ ${ }^{1}$ Fakultas Keguruan Ilmu Pendidikan, Universitas Muhammadiyah Tangerang, Indonesia \\ ${ }^{2}$ Fakultas Keguruan dan Ilmu Pendidikan, Universitas Sriwijaya, Indonesia \\ *Corresponding author. Email: Samsulazhar09@yahoo.com
}

\begin{abstract}
The aim of this study is to determine the increase of motoric skillson rhythmic gymnastics material. This is an action research using hypnoteaching method to improve motoric skills. Sample consists of 31 students (15 male and 16 female). The result of data analysis collected from activity in each cycle is collected. In the first cycle, the average score of students was $52 \%$, in cycle II the average score of students reached $62 \%$, and in the cycle III increased to $75 \%$. On the observation sheet, the teacher's action in the cycle I reached $46 \%$ and at the second meeting increased to $67 \%$. In the next cycle, the percentage of teacher activity in the second cycle of meeting I reached $73 \%$ and at the second meeting increased to $87 \%$. In last cycle II, first meeting action of teacher in learning reached $93 \%$ and was maximal $(100 \%)$ at the second meeting.In the cycle I of learning activities, first meeting reached $33 \%$, and it increased at the second meeting to 53\%. In the cycle II of first meeting, students activity reached $67 \%$ and at the second meeting increased to $80 \%$. At the end of the cycle III, during the first meeting, students' actions reach 93\% and was maximum (100\%) at the meeting II. The conclusion of this research is that hypnoteaching method can improve the learning process of rhythmic gymnastics.
\end{abstract}

Keywords: Motor Ability, Hypnoteaching Method, Gymnastic

\section{INTRODUCTION}

Education in the global era is no longer said to be a necessity but, education in this day and age is of great importance. Education is a right that must be obtained by everyone, because with education one can recognize the learning process. Through learning humans can undergo the process of change from who can not become a person who can by adding knowledge in education. Education is a learning of knowledge, skills and habits of a group of people that occur through learning. Government Regulation Number 19 Year 2005 in National Education Standards Agency provides an opportunity to complete a comprehensive curriculum in order to achieve national education objectives. One of the subjects in the existing curriculum is learning physical education. Physical education is an educational process that utilizes physical activity to produce a holistic change in the quality of the individual, both in terms of physical, mental, and emotional. "Physical education in elementary school refers to the same physical, mental, emotional, and social growth and development in forming and developing basic motion skills, instilling values, attitudes and familiarizing healthy living" [1]. Physical education and health is a process of learning through physical activity designed to improve physical fitness, knowledge, healthy living behavior, active, sportive attitude, emotional intelligence, developing skills and motor skills.
Motor skills in elementary school students is one factor that can affect the success of children in learning motor movement. Suggests the definition of ability is the capacity of the individual today to perform various tasks in a job [2]. The overall capability of its essence is built on two factors: intellectual and physical. In this case, ability is the effort that a person undertakes to complete his task in accordance with his physical condition. Physical ability is the capacity to perform tasks by demanding stamina, agility, strength, and similar characteristics. The ability possessed by a person depends on the energy and physical state it has. Motor skills (motion) owned by humans divided into three parts, namely the theory of motion, learning motion, and the development of motion [3]. Motion theory is the process of giving or explanation of the kinds of motion performed by the teacher, learning motion is an action (practice) that students do when given a motion example, while the development of motion is an exercise done by combining one by one movement to become a movement that can increase motor ability of the child. "The development of motor and skills of children experienced different periods of development" [3]. Ages 5-8 years old children begin dealing with the ability of body management and basic skills such as locomotor motion, non locomotor, and manipulative motion. In children aged above (9-11 years) began to master special skills. Starting from advanced manipulative activities, to 
rhythmic activities and games, gymnastics, activities in the water.

Teachers must know the motor skills of students in order to group based on the ability of motor movement in the process of learning physical education in school. Provide direction and guidance so that students are able to perform movements in accordance with the ability and physical conditions in accordance with its growth. It also depends on the age level of the child. Students entering primary school age average from 6-12 years. This age range has different phases of motor development. Determination of teaching materials and appropriate learning methodology is needed by educators to determine students' motor skills. The learning process of physical education and health will work well when determining the materials and methodology according to the students' motor skills accurately is one of the keys to successful education efforts. This means that teachers know the abilities, pleasure, and needs of children, so that teachers can help students to use their body more efficiently in performing various basic skills and skills are complex.

Hypnoteaching is one of the development of the latest learning methodology that have not been widely understood. So far knowing hypno is a science that makes people totally lost consciousness. Hypno is usually only known in the world of magic and medical, but in the world of hypno education also plays an important role. Science hypno in the world of education is used to facilitate the learning process. Hypnosis is also useful in overcoming problems related to physical or psychic conditions. This type of hypnosis is often called hypnoteaching. results of research undertaken by "the increase in learning motivation born of a learning process using hypnoteaching method with contextual approach, so students easy to understand the material if given examples are contextually linked material with daily environment" [4]. "Hypnoteaching is a learning process with the science of hypnosis is more focused on providing positive suggestions from teacher to student and student to themselves' [5]. This positive suggestion will be encouraged or ordered the subconscious mind in order to optimize the ability of the students had at the time in the classroom. "Hypnoteaching comes from the word hypnosis and teaching" [6]. Hypnoteaching is the art of communicating by giving suggestions for students to become more intelligent. Giving suggestions to students will make students aware that there is a potential that has not been optimized in learning. Based on the problem whether the hypnoteaching method can improve the motor skills of the grade IV student in Cibodas I Elementary School Tangerang City.

\section{METHOD}

The type of research used in this research is Classroom Action Research . There are several models of action research proposed by a number of characters, such as Kemmis and Mc Taggart models, Elliot models, Ebbut models, McKernan models, Hopkins models, and others. In this study, the classroom action research model used is a model developed Kemmis \& Taggart. "Classroom action research is a spiral cycle consisting of: (1) planning, (2) action, (3) observation, and (4) reflection. In the action model introduced by the acting component (action) with observing (observation) is made into a whole, the intention is both of these components due to the fact that between the application of action with observation is also directly implemented" [7].

Data analysis is an attempt to select, sort, discard, and classify data. In classroom action research there are two types of data that can be collected by researchers, namely. Quantitative data (value of student test result) can be analyzed descriptively. In this case using descriptive statistical analysis such as, looking for the average value and percentage of success. Qualitative data is data in the form of sentence-shaped information that provides an overview of student expression related to the level of ability and understanding of a learning.

\section{RESULTS}

Based on the description of learning physical education and health, especially the material gymnastics rhythm, the value obtained by students is still very less than the minimum thoroughness criteria of 75. Below are tables of students success rate as follows.

Table 1. Level of Student Success

\begin{tabular}{|c|c|c|}
\hline Number & Score & Category \\
\hline 1 & $85-100$ & Very Good \\
\hline 2 & $70-84$ & Good \\
\hline 3 & $60-69$ & Enough \\
\hline 4 & $50-59$ & Less \\
\hline 5 & $<50$ & Very Less \\
\hline
\end{tabular}

The treatment of action to apply hypnoteaching method aims to improve the motor skills of students of grade IV Cibodas 1 elementary school academic year 2017-2018. Improve the ability of students involved in every learning activity, the learning cycle I that starts from the planning stage, action, observation, and reflection.

Table 2. Recapitulation Mean Value of Rough Motor Capability the Grade IV Students Cycle I, II, and III Cibodas 1 Elementary School.

\begin{tabular}{|c|c|c|c|c|c|}
\hline \multirow{2}{*}{$\begin{array}{c}\text { Num } \\
\text { ber }\end{array}$} & $\begin{array}{c}\text { PGRI } \\
\text { rhythmic } \\
\text { gymnastics }\end{array}$ & Pra & \multicolumn{3}{|c|}{ Cycle } \\
\cline { 4 - 6 } & & $\begin{array}{c}\text { Cycle } \\
\text { I }\end{array}$ & $\begin{array}{c}\text { Cycle } \\
\text { II }\end{array}$ & $\begin{array}{c}\text { Cycle } \\
\text { III }\end{array}$ \\
\hline 1 & $\begin{array}{c}\text { Average } \\
\text { value }\end{array}$ & 40 & 52,1 & 62,4 & 75,4 \\
\hline
\end{tabular}

Based on the average value can be seen that the number of students who achieve the criteria mastery of a minimum of $\geq 75$ experienced a significant improvement. The average value of students' gross motor skills in the initial conditions before the action dalah 40 . In cycle I has increased the average value of 52, 1, the cycle II increased again to 62.4 , and at the end of the cycle that is the third cycle average student score reached 75.4. These improvements prove that hypnoteaching method can 
improve students' gross motor skills especially in PGRI rhythmic gymnastics material. It can be reflected that the learning of PGRI cadence exercises performed by teachers can be declared successful.

\section{CONCLUSION}

Based on the research that has been done using the method of hypnoteaching. Material gymnastics rhythm of students motor skills increased from cycle I to maximum in cycle III. Cycle I achievement of the average score of $52 \%$ students, in cycle II the average score of students reach $62 \%$, and in the third cycle increased to $75 \%$. On the observation sheet the teacher's action in the first cycle I learning meeting reached $46 \%$ and at the second meeting increased to $67 \%$. Continue on the next cycle that is cycle II meeting percentage of teacher activity reaches $73 \%$ and at the second meeting increased to $87 \%$. At the end of the cycle II of meeting I, teacher action in learning reached 93\% and maximum at meeting II is $100 \%$.

Based on the results of the research and the conclusion, the researcher put forward the following suggestions (1) Teachers should collaborate more on learning methodology that will be used for teaching, so as to create a comfortable, fun, motivating, and focused learning environment and achieving the expected learning objectives. (2) To the researcher more creative and intelligent use of learning methodology and develop learning in the classroom in accordance with the learning curriculum. (3) To the reader, this research is expected to be used as references material and additional material for further research.

\section{REFERENCES}

[1] Rosdiani, Dini, "Model of Direct Learning in Physical Education and Health," Bandung; Alfabeta. 2012, pp, 56-65.

[2] Robbins, P Stephen, and Timothy, Judge, "Organizational Behavior (Organizational Behavior)," Jakarta; Salemba four. 2015, pp, 7789.

[3] Rahyubi, Heri, "Learning Theory and Motorized Learning Applications," Bandung; Nusa Media. 2014, pp, 45-65.

[4] Kasmaja, "Referencess Effectiveness of Implementation of Hypnoteaching Method for Increasing Motivation and Learning Result of Math on Junior High School Student," J. of EST, Volume 2 no. 1, pp, 102-105. Mei. 2016.

[5] Dj, Muhammad $Z$ and Sukarnianti, "Using Hypnoteaching Strategy to Improve Students Writing Ability," J. Dinamika Ilmu, Volume. 15, no.2, Jan. 2015.

[6] Nisa, Hanna, "Hypnoteaching for Paud and Kindergarten," Yogyakarta: Diva Press. 2014.

[7] Mawardi, "Classroom Action Research Module," Tangerang: Teacher Training and Education
Faculty of Muhammadiyah University of Tangerang. 2016. 